\title{
Determination of food sources for benthic invertebrates and brook trout Salvelinus fontinalis in Canadian Boreal Shield lakes using stable isotope analysis
}

\author{
Patricia Glaz ${ }^{1, *}$, Pascal Sirois ${ }^{2}$, Christian Nozais ${ }^{1}$ \\ ${ }^{1}$ Département de biologie et centre d'études nordiques, Université du Québec à Rimouski, Rimouski, Québec G5L 3A1, Canada \\ ${ }^{2}$ Laboratoire des sciences aquatiques, Département des sciences fondamentales, Université du Québec à Chicoutimi, \\ Chicoutimi, Québec G7H 2B1, Canada
}

\begin{abstract}
Allochthonous inputs can be an important contribution of organic matter in lake ecosystems. Yet, our understanding of the patterns of energy dependence of littoral invertebrates and fish is poor. We measured carbon $\left(\delta^{13} \mathrm{C}\right)$ and nitrogen $\left(\delta^{15} \mathrm{~N}\right)$ stable isotope values for primary producers, terrestrial detritus, benthic macroinvertebrates, zooplankton and brook trout Salvelinus fontinalis in 8 oligotrophic Canadian Boreal Shield lakes to determine food sources that support benthic consumers and brook trout. Mixing models used to determine animal diets from stable isotope analysis showed leaf litter to be the principal food source for benthic primary consumers in 6 out of 8 lakes. Brook trout derived its carbon mainly from benthic predatory macroinvertebrates in all lakes, with a contribution ranging from 60 to $90 \%$. Zooplankton also contributed to brook trout diet in 3 of 8 lakes, ranging from 28 to $37 \%$. $\delta^{15} \mathrm{~N}$ increased from primary producers to consumers at different trophic positions in all lakes. Nitrogen isotopic signatures of brook trout became more positive with increasing fish length, indicating a change in fish foraging strategy related to size. Our study (1) suggests that carbon from terrestrial habitat (leaf litter) may contribute significantly to the food web of oligotrophic Canadian Boreal Shield lakes and (2) highlights the importance of carbon originating from benthic habitats in supporting brook trout in these lakes.
\end{abstract}

KEY WORDS: Allochthonous subsidies · Benthic macroinvertebrates · Zooplankton · Brook trout · Diet breadth $\cdot$ Size-related diet shift $\cdot$ Stable isotopes $\cdot$ Boreal lakes

\section{INTRODUCTION}

Organic matter that supports consumers in lakes can be produced within the ecosystem (autochthonous matter) or imported into the systems from adjacent terrestrial habitats (allochthonous matter). In low-productivity lakes that dominate in the boreal ecoregion, the relative availability of these resources is controlled by allochthonous terrestrial inputs (i.e. leaf litter falling from riparian vegetation; Ask et al. 2009, Karlsson et al. 2009). Thus, lakes are coupled to watershed inputs of organic matter as movements of organic matter connect terrestrial ecosystems with aquatic food webs (Pace et al. 2004). Moreover, because the vast majority of lakes in this region are small and shallow and their perimeter to area ratios are relatively high (Schindler \& Scheuerell 2002), they can be highly influenced by allochthonous organic matter of terrestrial origin (Weidel et al. 2008, Premke et al. 2010, Solomon et al. 2011).

Littoral zones are known to receive large inputs of allochthonous matter from riparian vegetation (Schindler \& Scheuerell 2002). Most current studies have focused on the pelagic food webs. However, lit- 
toral benthic pathways often play a key role in lake production and food web dynamics (Vadeboncoeur et al. 2002). Indeed, littoral benthic macroinvertebrates are an important heterotrophic component of lake ecosystems and constitute a link between basal resources and upper trophic levels in the food web such as fishes (Vander Zanden \& Vadeboncoeur 2002, Vander Zanden et al. 2006). Knowledge of the relative importance of allochthonous matter sources supporting benthic macroinvertebrates and ultimately fish is still poor (Carpenter et al. 2005, Solomon et al. 2008). However, Cole et al. (2006) showed that in oligotrophic lakes between 60 and $85 \%$ of benthic macroinvertebrates used allochtonous organic matter to meet their energy requirements.

A variety of processes at multiple trophic levels create linkages among terrestrial, pelagic and benthic energy pathways in lakes (Schindler \& Scheuerell 2002, Vadeboncoeur et al. 2002). For instance, benthic consumers may utilize dissolved or particulate detritus of terrestrial origin, and fishes may consume benthic, pelagic, or terrestrial prey (Solomon et al. 2011). Many fishes use both benthic and pelagic habitats or undergo ontogenic habitats shifts, integrating benthic and pelagic food webs (Vadeboncoeur et al. 2002). Brook trout Salvelinus fontinalis is a widely distributed and economically important fish species of eastern Canadian Boreal Shield lakes (Power 1980). It has been identified as a generalist carnivore fish that feeds mainly on benthic macroinvertebrates (Tremblay \& Magnan 1991, Lacasse \& Magnan 1992), but also on zooplankton, terrestrial insects (Power et al. 2002, Tremblay-Rivard 2007) and fish, including brook trout (Magnan 1988, Lacasse \& Magnan 1992). Recent studies have shown that stable isotope signatures could be used to identify intraspecific shifts in feeding strategies of brook trout (Power et al. 2002, Tremblay-Rivard 2007). However, little is known about brook trout diet and size-related diet shifts in lakes of the Canadian Boreal Shield.

In this study, we measured naturally occurring carbon and nitrogen stable isotope ratios of basal resources (terrestrial detritus, macrophytes, periphyton, sediment organic matter), benthic organisms, zooplankton and brook trout in 8 oligotrophic Canadian Boreal Shield lakes. Using stable isotope analysis we examined feeding relationships among consumers. Our objectives were to: (1) determine the ultimate sources from which benthic primary consumers derive their energy in order to evaluate the relative importance of allochthonous organic matter for these consumers and (2) identify brook trout diet breadth and size-related diet shifts.

\section{MATERIALS AND METHODS}

\section{Study area}

The study was conducted in the province of Que-

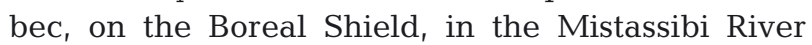
drainage basin. The study area is dominated by virgin black spruce Picea mariana forests. Eight oligotrophic lakes with similar morphometric characteristics were selected in a territory covered by pristine boreal forest that was recently accessible by a network of forestry roads (Table 1). In all lakes, the only fish species found was brook trout, except for Lake 8, in which brook trout coexists with white sucker Catostomus commersoni.

\section{Sampling}

Eight lakes were sampled in July 2008. Water samples and $\mathrm{pH}$ measurements were taken at 5 littoral sampling stations set uniformly around each lake. At each sampling station, $\mathrm{pH}$ was measured at the subsurface using a YSI 556 MPS probe. Water transparency was estimated with a Secchi disk at the deepest part in each lake. Water samples (4 l) were collected at each littoral station at $50 \mathrm{~cm}$ below the surface with an Alpha bottle for the determination of chlorophyll a (chl a), dissolved organic carbon (DOC), total phosphorus (TP) concentrations and isotopic analysis of particulate organic matter (POM). Terrestrial detritus (leaf litter, woody debris), macrophytes, periphyton (epilithon and epixylon), surface sediment organic matter (SOM), benthic macroinvertebrates, zooplankton and brook trout were sampled for stable isotope analysis. Terrestrial detritus, macrophytes and SOM were hand-collected in the littoral zone of lakes and placed in scintillation vials. Periphyton was collected by scraping from rocks and woody debris in the littoral zone and placed in scintillation vials. Benthic invertebrates were collected in the littoral zone using a Turtox Dnet with a mesh size of $500 \mu \mathrm{m}(\mathrm{n}=3$ replicates per station) and placed in cooler boxes. Zooplankton samples were obtained by towing a plankton net (mouth opening $20 \mathrm{~cm}$, mesh $53 \mu \mathrm{m}$ ) mounted alongside a boat for 5 to $10 \mathrm{~min}$. Zooplankton were then placed in Ziploc ${ }^{\circledR}$ bags containing water. Fish were captured with 6 experimental gill nets, according to the Quebec Ministry of Natural Resources and Wildlife standard protocol (mesh sizes of 1, 1.5, 2, 2.5, 3 , and 3.5 inches [ 25 to $90 \mathrm{~mm}$ ]) set simultaneously around the lake, perpendicular to the shore with the 
small mesh always set toward the shore. Gill nets were left overnight for $12 \mathrm{~h}$. All fish samples were placed in cooler boxes and transported to the laboratory for processing.

\section{Sample preparation and analyses}

Water samples for the determination of chl a were filtered (200 $\mathrm{ml}$ or more) onto Whatman GF/F filters. Pigments were extracted for $24 \mathrm{~h}$ in $90 \%$ acetone, at $5^{\circ} \mathrm{C}$ in the dark without grinding. Chl a was determined using the Welschmeyer et al. (1993) method. DOC was determined by filtering subsamples of water through precombusted $\left(500^{\circ} \mathrm{C}, 5 \mathrm{~h}\right)$ Whatman $\mathrm{GF} / \mathrm{F}$ filters. The filtrate was placed in glass vials with teflon-lined caps and acidified with $25 \% \mathrm{v} / \mathrm{v} \mathrm{H}_{3} \mathrm{PO}_{4}$ $\left(10 \mu \mathrm{ml}^{-1}\right)$. DOC values were obtained using a TOC5000A analyzer (Shimadzu), following the protocol of Whitehead et al. (2000). DOC reference standards were produced by the Hansell's Certified Reference Materials (CRM) program. Total phosphorus (TP) was measured using the molybdenum blue method (Stainton et al. 1977) after autoclaving $50 \mathrm{ml}$ samples with $0.5 \mathrm{~g}$ of potassium persulfate for $1 \mathrm{~h}$ at $120^{\circ} \mathrm{C}$. For the determination of isotopic signatures of POM, subsamples of water were filtered through precombusted $\left(500^{\circ} \mathrm{C}, 5 \mathrm{~h}\right)$ Whatman $\mathrm{GF} / \mathrm{F}$ filters and stored frozen at $-20^{\circ} \mathrm{C}$ until analysis. Terrestrial detritus, macrophytes, periphyton and SOM samples were cleared and separated with the aid of a dissecting microscope. Benthic macroinvertebrates and zooplankton samples were identified at the order or family level using Merritt \& Cummins (1996) and Edmondson (1959) respectively. After identification, benthic macroinvertebrates were frozen separately at $-20^{\circ} \mathrm{C}$ while zooplankton was frozen as a pool of organisms at $-20^{\circ} \mathrm{C}$. The total length of each brook trout was recorded. A $2 \mathrm{~cm}$ square and $1 \mathrm{~cm}$ deep block of dorsal white muscle without skin sample was taken from 25 brook trout in each lake. All muscle samples were kept frozen at $-20^{\circ} \mathrm{C}$ in scintillation vials until analysis.

\section{Stable isotope analyses}

POM filters, terrestrial detritus, macrophytes, periphyton, SOM, whole benthic invertebrates, zooplankton, and brook trout samples were dried at $60^{\circ} \mathrm{C}$ for $48 \mathrm{~h}$. Mortar and pestle were thereafter used to grind samples into a fine powder (except for POM filters). Powder and filter samples were then encapsulated in pressed tin capsules $(5 \times 9 \mathrm{~mm})$ and tin foil cups (Costech Analytical Technology), respectively. Encapsulated dry mass was approximately $1 \mathrm{mg}$ for terrestrial detritus, macrophytes, periphyton, benthic invertebrates, zooplankton, and brook trout muscle tissue and $3 \mathrm{mg}$ for SOM. Lipid correction techniques were not considered in our analyses because of low carbon to nitrogen (C:N) ratio values (Vander Zanden \& Rasmussen 1999). Previous studies showed that lipids are lower in animals analyzed as muscle tissue, as in our study for fish, than animals analyzed as whole (McCutchan et al. 2003). C:N ratio values for fish varied between 3.9 (Lake 7 ) and 4.7 (Lake 6) in our study.

Analyses of stable isotopes ratios of $\mathrm{C}\left(\delta^{13} \mathrm{C}\right)$ and $\mathrm{N}$ $\left(\delta^{15} \mathrm{~N}\right)$ were carried out at the Institut des sciences de la mer (ISMER, Rimouski, Quebec, Canada) using a COSTECH ECS 4010 Elemental Analyser coupled with a DeltaPlus XP Isotope Ratio Mass Spectrometer (IRMS, Thermo Electron). System control as well as acquisition and treatment of the data were carried out using the Isodat 2 software. Stable isotope ratios were expressed in $\delta$ notation as parts per thousand (\%) according to the equation:

$$
\delta \mathrm{X}=\left[\left(\mathrm{R}_{\text {sample }} / \mathrm{R}_{\text {standard }}\right)-1\right] \times 1000
$$

where $\mathrm{X}$ is ${ }^{13} \mathrm{C}$ or ${ }^{15} \mathrm{~N}$ and $\mathrm{R}$ is the corresponding ${ }^{13} \mathrm{C}:{ }^{12} \mathrm{C}$ or ${ }^{15} \mathrm{~N}:{ }^{14} \mathrm{~N}$ ratios.

International standards used for the measurement were Vienna Pee Dee Belemite (VPDB) limestone for ${ }^{13} \mathrm{C}$ and atmospheric nitrogen for ${ }^{15} \mathrm{~N}$. Regional standards for in-lab normalization regressions to determine sample $\delta$ values were anhydrous caffeine (Sigma Chemical), Mueller Hinton Broth (Becton Dickinson) and Nannochloropsis, respectively. These homemade standards were calibrated once a year using standards from the National Institute of Standards and Technology (NIST). Replicate analyses of standards gave analytical errors (SD) of $\pm 0.30 \%$ o for $\mathrm{C}$ and $\pm 0.18 \%$ for $\mathrm{N}$.

\section{Data analyses}

To estimate the relative contribution of the different food sources to the diet of benthic invertebrates and brook trout, we adopted a Bayesian multi-source stable isotope mixing model, available as an open source R package (SIAR, Parnell et al. 2010). SIAR takes data on organism isotopes and fits a Bayesian model to their dietary habits based on a Gaussian likelihood with a dirichlet distribution prior mixture on the mean. SIAR offers a number of advantages over earlier mixing models; it can incorporate trophic 
enrichment factors within the model and known C and $\mathrm{N}$ concentrations dependence, assuming that for each element, a source's contribution is proportional to the contributed mass times the elemental concentration in that source. We assumed a trophic enrichment of $+1 \%$ for ${ }^{13} \mathrm{C}$ (De Niro \& Epstein 1978) and $+3.4 \%$ for ${ }^{15} \mathrm{~N}$ (Minagawa \& Wada 1984). To assess these trophic enrichment assumptions, we combined organisms into main groups of consumers: zooplankton, benthic primary consumers and predatory macroinvertebrates and calculated average $\delta^{13} \mathrm{C}$ and $\delta^{15} \mathrm{~N}$ for each group.

Using Daphnia spp. as the baseline trophic level, trophic position of consumers was calculated using the formula given in Vander Zanden \& Rasmussen (2001):

Trophic position consumer $=$

$$
\left(\delta^{15} \mathrm{~N}_{\text {consumer }}-\delta^{15} \mathrm{~N}_{\text {baseline }}\right) / f+2
$$

where $\delta^{15} \mathrm{~N}_{\text {consumer }}$ is the $\delta^{15} \mathrm{~N}$ value of the consumer for which the trophic position is estimated, $\delta^{15} \mathrm{~N}_{\text {baseline }}$ is the $\delta^{15} \mathrm{~N}$ of the baseline organism, 2 is the expected trophic position of the organism used to estimate baseline $\delta^{15} \mathrm{~N}$, and $f$ is the fractionation factor between a predator and its prey which corresponds to 1 trophic level. We used the fractionation factor of $3.4 \%$ as proposed by Minagawa \& Wada (1984) and generally used in studies estimating trophic position of aquatic consumers (Vander Zanden et al. 1997).

Stable isotopes of carbon and nitrogen were also individually plotted against fish length in each lake. Simple linear regressions were then calculated for each lake.

\section{RESULTS}

Physico-chemical data for the 8 lakes are outlined in Table 1. The lakes are small $\left(0.031\right.$ to $\left.0.288 \mathrm{~km}^{2}\right)$, as are their catchments $\left(0.202\right.$ to $\left.2.895 \mathrm{~km}^{2}\right)$. All the lakes are relatively shallow (maximum depth $<9 \mathrm{~m}$ ) and exhibited low levels of phytoplankton biomass (chl a) but high DOC concentrations (Table 1). This is typical of oligotrophic Canadian Shield lakes, which are slightly acidic, with high concentrations of humic materials (Power et al. 2002, Glaz et al. unpubl.).

\section{Benthic consumers and potential food sources}

Mayflies (Ephemeroptera), corixids (Corixidae), amphipods (Amphipoda) and caddisflies (Trichoptera), all of them non-predatory macroinverte-

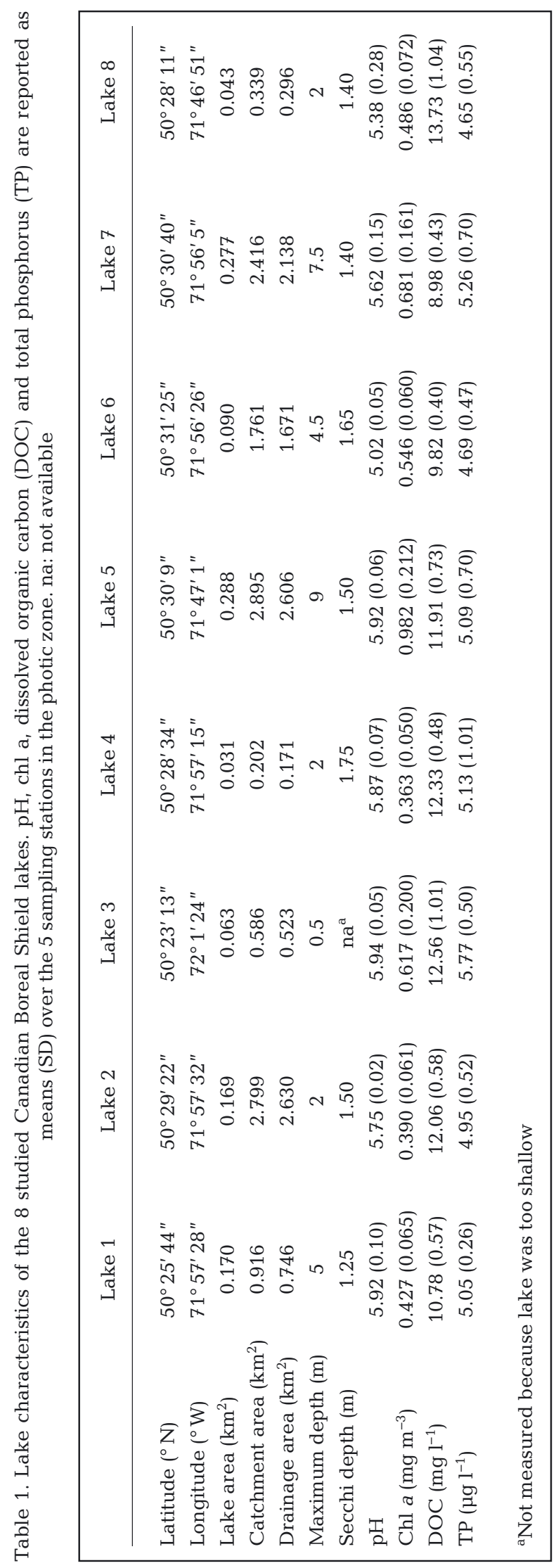


brates, were grouped as benthic primary consumers. Leeches (Hirudinea), water mites (Hydracarina), dragonflies (Anisoptera), damselflies (Zygoptera), dysticids (Dysticidae) and alderflies (Sialidae), all of them active predators, and Empidids (Empididae) and Chironomids (Chironomidae), which are mainly predators, were enriched in ${ }^{15} \mathrm{~N}$ relative to primary consumers in all lakes (Fig. 1). Consequently, these organisms were pooled as predatory macroinvertebrates. A mixing model was performed to evaluate basal resource contribution to benthic primary consumers. Benthic primary consumers derive their carbon mainly from leaf litter in all lakes (Table 2). However, in Lakes 1 and 2 epilithon and epixylon also contributed to their diet, with mean contributions of 43 and $46 \%$ respectively (Table 2 ).

\section{Brook trout diet breath}

Brook trout mean carbon isotope ratios ranged from -31.1 (Lake 8) to $-26.2 \%$ (Lake 3) and mean nitrogen isotopes ratios ranged from 5.6 (Lake 1) to $6.4 \%$ (Lake 4). Both $\delta^{13} \mathrm{C}$ and $\delta^{15} \mathrm{~N}$ signatures for brook trout were well separated from their potential prey items in all lakes. Brook trout were enriched in ${ }^{15} \mathrm{~N}$ relative to all other sources in all lakes (Fig. 1). The mixing model confirmed that brook trout derive their carbon biomass mainly from predatory benthic macroinvertebrates in all lakes, with feasible mean contributions ranging from 60 (Lake 2) to $90 \%$ (Lake 3) (Table 3). However, in Lakes 1, 2 and 8, zooplankton also appeared as a potentially important food resource with feasible mean contributions of 28 , 37 and $32 \%$ respectively. The mixing model also indicated that brook trout do not depend on benthic primary consumers for food (Table 3).

\section{Trophic position}

$\delta^{15} \mathrm{~N}$ increased from primary producers to consumers at different trophic positions in all lakes (Fig. 1), indicating that the heavy nitrogen isotope $\left({ }^{15} \mathrm{~N}\right)$ was preferentially retained during nutrient assimilation and incorporation into animal tissues. Brook trout were enriched in ${ }^{15} \mathrm{~N}$ by $3.77 \%$ relative to predatory macroinvertebrates when all lakes were pooled (Table 4). However, predatory macroinvertebrates were only enriched by $2.60 \%$ in ${ }^{15} \mathrm{~N}$ relative to benthic primary consumers (Table 4 ).

Mean trophic position of consumers was significantly different among the 3 main trophic groups examined in all lakes (Table 5). The a posteriori Tukey test confirmed the existence of significant differences for all paired combinations in all lakes. Predatory macroinvertebrates had a mean trophic position that was significantly higher than that of benthic primary consumers and fish had a significantly higher trophic position than both benthic primary consumers and predatory macroinvertebrates in all lakes (Table 5).

\section{Size-related diet shift of brook trout}

Brook trout mean length ranged from 192 (Lake 8) to $245 \mathrm{~mm}$ (Lake 2). Brook trout showed great variability in $\delta^{13} \mathrm{C}$ values and they became significantly more depleted in ${ }^{13} \mathrm{C}$ with increasing length in Lakes 2, 4 and 8 (although in Lake 4 sampling size was low, $\mathrm{n}=8$, in comparison to the other lakes, $\mathrm{n}=$ 25). Lakes 1, 3, 5, 6 and 7 did not show any particular pattern in relation to increasing fish length (Fig. 2a, Table 6). Brook trout became significantly more enriched in ${ }^{15} \mathrm{~N}$ with increasing body length in all lakes but Lake 4, and this relationship was also significant when all lakes were pooled (Fig. 2b, Table 7).

\section{DISCUSSION}

Leaf litter appeared to be the principal carbon source for benthic primary consumers in 7 out of our 8 lakes, suggesting a significant contribution of allochthonous matter to the littoral food web. Brook trout seemed to derive their food mainly from benthic predatory macroinvertebrates in all lakes, although zooplankton also contributed to brook trout diet in 3 out of 8 lakes. A size-related diet shift was also observed for brook trout as they became ${ }^{15} \mathrm{~N}$-enriched with increasing body length. However, no consistent pattern was observed for $\delta^{13} \mathrm{C}$ values.

\section{Carbon flow in lake food webs}

In oligotrophic lakes, humic matter originating in the catchment can be an important contribution of allochthonous matter for aquatic organisms (France 1997, Glaz et al. unpubl.). Moreover, the loading of allochthonous matter can greatly exceed autochthonous primary production (Carpenter et al. 2005). High DOC concentrations strongly influence light penetration in lakes (Carignan et al. 2000, Karlsson et al. 2009) and present an unfavorable environment 


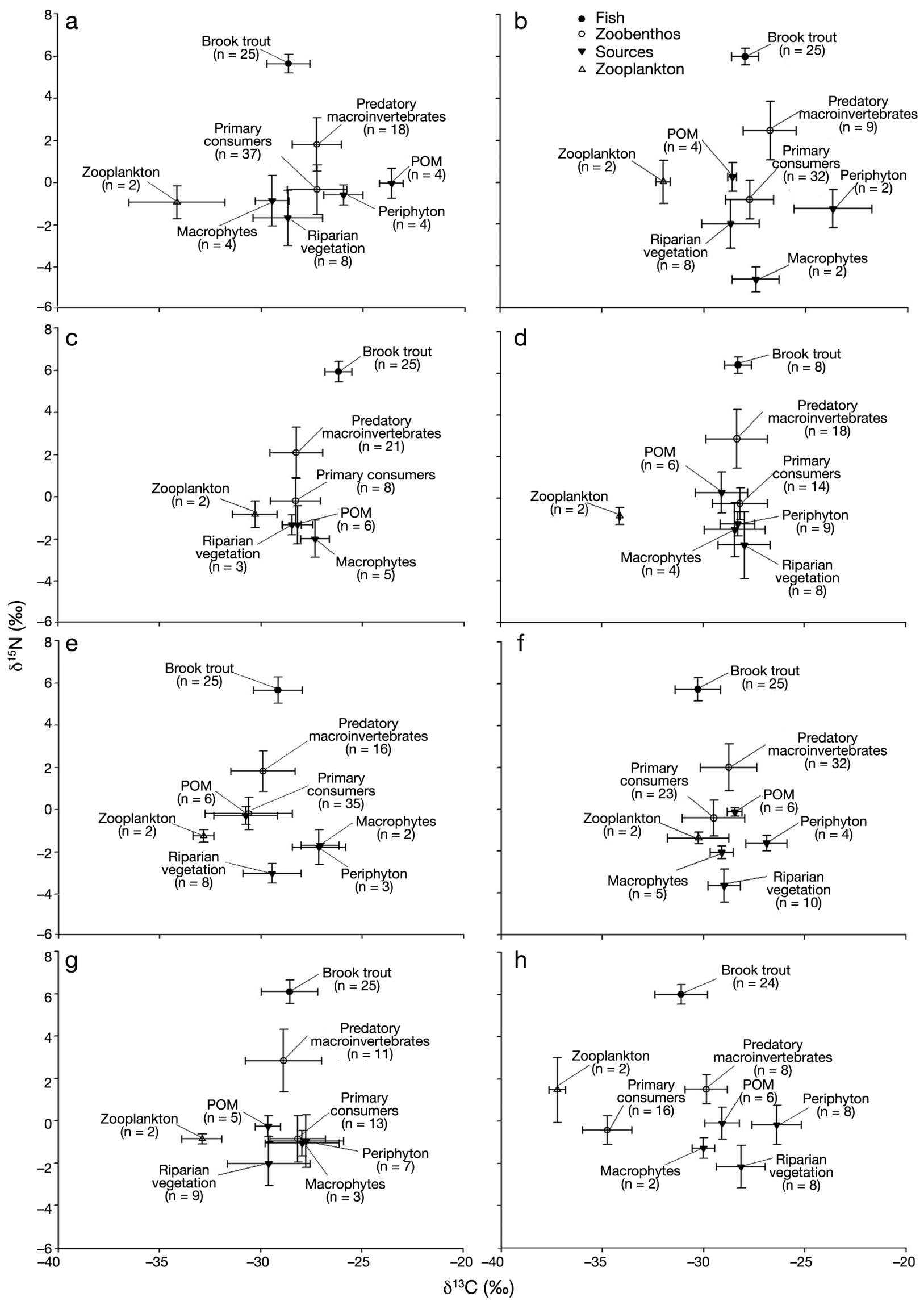

Fig. 1. Stable isotope signatures of carbon $\left(\delta^{13} \mathrm{C}\right)$ and nitrogen $\left(\delta^{15} \mathrm{~N}\right)$ for potential food sources and brook trout for 8 lakes: (a) Lake 1; (b) Lake 2; (c) Lake 3; (d) Lake 4; (e) Lake 5; (f) Lake 6; (g) Lake 7 and (h) Lake 8. Error bars represent the mean \pm SE. POM: particulate organic matter 
Table 2. Bayesian mixing model (SIAR) results for benthic primary consumers in 8 lakes. Percentiles show the 1st to 99th range of potential contribution. Sources with a necessary contribution (minimal potential contribution $>0 \%$ ) in bold. abs: absent

\begin{tabular}{|c|c|c|c|c|c|c|c|c|c|c|}
\hline \multirow{2}{*}{ Lake } & \multicolumn{2}{|c|}{ Leaf litter } & \multicolumn{2}{|c|}{ Epilithon } & \multicolumn{2}{|c|}{ Epixylon } & \multicolumn{2}{|c|}{ Macrophytes } & \multicolumn{2}{|c|}{ POM } \\
\hline & Mean & Percentile & Mean & Percentile & Mean & Percentile & Mean & Percentile & Mean & Percentile \\
\hline 1 & 43 & $26-59$ & abs & & 43 & $29-56$ & 7 & $0-20$ & 6 & $0-19$ \\
\hline 2 & 36 & $10-58$ & 10 & $0-20$ & abs & & 46 & $28-66$ & 7 & $0-19$ \\
\hline 3 & 44 & $25-63$ & 3 & $0-9$ & abs & & 27 & $0-49$ & 26 & $0-49$ \\
\hline 4 & 52 & $40-66$ & 17 & $0-35$ & 10 & $0-26$ & 13 & $0-31$ & 7 & $0-20$ \\
\hline 5 & 95 & $90-99$ & 2 & $0-5$ & abs & & 1 & $0-4$ & 1 & $0-3$ \\
\hline 6 & 78 & $68-87$ & abs & & 4 & $0-11$ & 6 & $0-17$ & 8 & $0-17$ \\
\hline 7 & 47 & $23-71$ & 7 & $0-20$ & 22 & $0-44$ & 11 & $0-27$ & 11 & $0-31$ \\
\hline 8 & 57 & $45-70$ & 7 & $0-20$ & 10 & $0-25$ & 12 & $0-28$ & 13 & $0-28$ \\
\hline
\end{tabular}

Table 3. Salvelinus fontinalis. Bayesian mixing model (SIAR) results for brook trout in 8 lakes. Percentiles show the 1st to 99th range of potential contribution. Sources with a necessary contribution (minimal potential contribution $>0 \%$ ) in bold

\begin{tabular}{|lcccccc|}
\hline Lake & \multicolumn{2}{c}{ Zooplankton } & \multicolumn{2}{c}{$\begin{array}{c}\text { Benthic primary } \\
\text { consumers }\end{array}$} & \multicolumn{2}{c|}{$\begin{array}{c}\text { Predatory } \\
\text { macroinvertebrates } \\
\text { Mean }\end{array}$} \\
& Mean & Percentile & Mean & Percentile & Percile \\
\hline 1 & $\mathbf{2 8}$ & $\mathbf{2 0 - 3 6}$ & 3 & $0-9$ & $\mathbf{6 8}$ & $\mathbf{5 8 - 7 9}$ \\
2 & $\mathbf{3 7}$ & $\mathbf{3 0 - 4 5}$ & 2 & $0-7$ & $\mathbf{6 0}$ & $\mathbf{5 1 - 6 8}$ \\
3 & 2 & $0-5$ & 8 & $0-17$ & $\mathbf{9 0}$ & $\mathbf{8 0 - 9 9}$ \\
4 & 13 & $0-24$ & 14 & $0-35$ & $\mathbf{7 3}$ & $\mathbf{4 8 - 9 3}$ \\
5 & 5 & $0-13$ & 8 & $0-19$ & $\mathbf{8 6}$ & $\mathbf{7 4 - 9 7}$ \\
6 & 6 & $0-14$ & 7 & $0-17$ & $\mathbf{8 6}$ & $\mathbf{7 6 - 9 7}$ \\
7 & 13 & $0-23$ & 6 & $0-15$ & $\mathbf{8 0}$ & $\mathbf{7 0 - 8 9}$ \\
8 & $\mathbf{3 2}$ & $\mathbf{2 3 - 4 2}$ & 3 & $0-8$ & $\mathbf{6 4}$ & $\mathbf{5 5 - 7 3}$ \\
\hline
\end{tabular}

Table 4. Mean $( \pm \mathrm{SD})$ nitrogen $\left(\delta^{15} \mathrm{~N}\right)$ and carbon $\left(\delta^{13} \mathrm{C}\right)$ stable isotope signatures of principal groups of consumers. All lakes were pooled

\begin{tabular}{|lrr|}
\hline & $\delta^{15} \mathrm{~N}(\%)$ & $\delta^{13} \mathrm{C}(\% \circ)$ \\
\hline Fish & $5.93(0.48)$ & $-28.70(1.02)$ \\
Predatory macroinvertebrates & $2.16(1.20)$ & $-28.52(1.40)$ \\
Benthic primary consumers & $-0.44(0.93)$ & $-29.33(1.45)$ \\
Zooplankton & $-0.57(0.64)$ & $-32.97(0.91)$ \\
\hline
\end{tabular}

Table 5. Mean $( \pm \mathrm{SD})$ trophic-position estimates in all lakes and analysis of variance (ANOVA) results comparing estimates between benthic primary consumers, predatory macroinvertebrates and fish in 8 lakes. The a posteriori Tukey test confirmed the existence of significant differences for all paired combinations in all lakes. Significance level $\alpha=0.05$

\begin{tabular}{|lccccc|}
\hline Lake & $\begin{array}{c}\text { Benthic primary } \\
\text { consumers }\end{array}$ & $\begin{array}{c}\text { Predatory } \\
\text { macroinvertebrates }\end{array}$ & Fish & $F$ & $\mathrm{p}$ \\
\hline 1 & $2.31(0.34)$ & $2.87(0.41)$ & $4.09(0.13)$ & 240.71 & $<0.001$ \\
2 & $2.21(0.43)$ & $2.97(0.52)$ & $3.97(0.12)$ & 168.10 & $<0.001$ \\
3 & $2.63(0.33)$ & $3.23(0.38)$ & $4.41(0.14)$ & 172.34 & $<0.001$ \\
4 & $2.25(0.21)$ & $3.18(0.53)$ & $4.22(0.12)$ & 90.04 & $<0.001$ \\
5 & $2.40(0.24)$ & $3.11(0.30)$ & $4.09(0.18)$ & 446.22 & $<0.001$ \\
6 & $2.23(0.25)$ & $2.91(0.34)$ & $4.03(0.16)$ & 269.27 & $<0.001$ \\
7 & $1.90(0.26)$ & $2.99(0.44)$ & $4.00(0.16)$ & 323.14 & $<0.001$ \\
8 & $2.08(0.32)$ & $2.73(0.25)$ & $3.85(0.14)$ & 324.13 & $<0.001$ \\
Pooled mean & $2.25(0.30)$ & $2.99(0.40)$ & $4.08(0.14)$ & & \\
\hline
\end{tabular}

for photosynthetic fixation of carbon in situ by autotrophic phytoplankton (Jones 1992), limiting autochthonous production. This is consistent with the low chl $a$ and high DOC values encountered in our studied lakes.

This study demonstrates that allochthonous matter (leaf litter) is the main food source contributor of benthic primary consumers, although benthic algae also contributed to their diet in Lakes 1 and 2. Also, since primary consumers are prey for predatory invertebrates (Merritt \& Cummins 1996) that are, in turn, principal dietary items for fish, allochthonous matter assimilated by primary consumers is transferred up the food web. Benthic invertebrates would be then the primary link between terrestrial carbon and fish. Our results support an emerging consensus that terrestrial and benthic support of lake food webs can be substantial (Vadeboncoeur et al. 2002, Premke et al. 2010, Solomon et al. 2011).

\section{Trophic position}

Our results enabled the description of the vertical structure of the food web using $\delta^{15} \mathrm{~N}$. Benthic primary consumers, predatory macroinvertebrates and fish had mean trophic positions of $2.25,2.99$ and 4.08 respectively. If we consider primary producers as Trophic level 1, then trophic levels of these groups would be 1.25, 1.99 and 3.08 respectively. These results are 

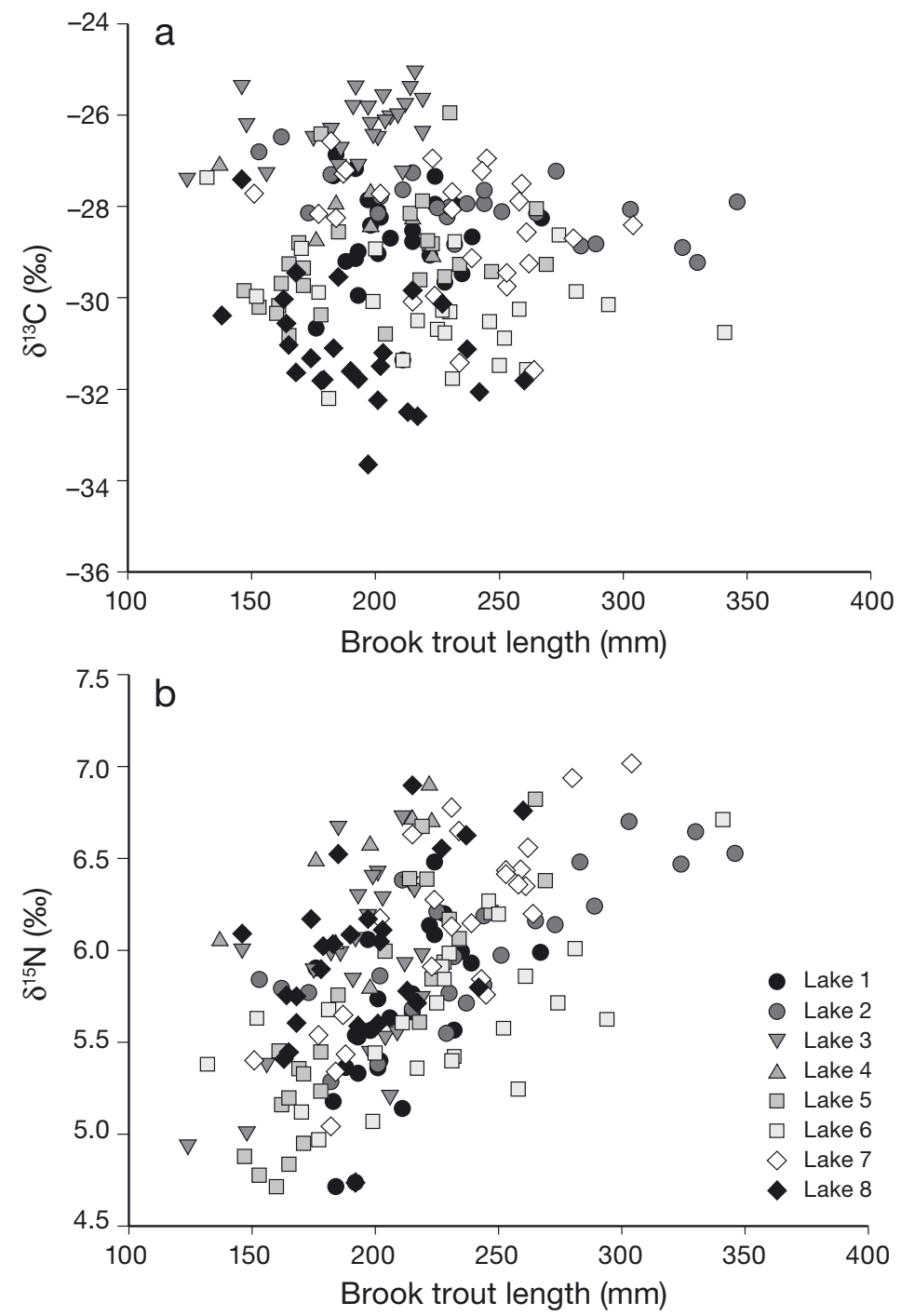

Fig. 2. Salvelinus fontinalis. Changes in brook trout (a) carbon $\left(\delta^{13} \mathrm{C}\right)$ and $(\mathrm{b})$ nitrogen $\left(\delta^{15} \mathrm{~N}\right)$ stable isotope signatures with increasing fish length in 8 lakes

Table 6. Salvelinus fontinalis. Simple regression results of carbon stable isotope ratio $\left(\delta^{13} \mathrm{C}\right)$ against brook trout length in 8 lakes. ${ }^{* *} \mathrm{p}<0.001,{ }^{*} \mathrm{p}<0.05$

\begin{tabular}{|lcrcrl|}
\hline Lake & $\mathrm{n}$ & \multicolumn{1}{c}{ Slope } & $\mathrm{r}^{2}$ & $F$ & $\mathrm{p}$ \\
\hline 1 & 25 & 0.0008 & 0.0003 & 0.0061 & 0.9383 \\
2 & 24 & -0.0081 & 0.4058 & 15.0264 & $0.0008^{* *}$ \\
3 & 25 & 0.0104 & 0.1508 & 4.0847 & 0.0551 \\
4 & 8 & -0.0173 & 0.5643 & 7.7710 & $0.0317^{*}$ \\
5 & 25 & 0.0125 & 0.1436 & 3.8573 & 0.0617 \\
6 & 24 & -0.0072 & 0.0911 & 2.2056 & 0.1517 \\
7 & 25 & -0.0125 & 0.1176 & 3.0645 & 0.0934 \\
8 & 24 & -0.0185 & 0.1899 & 5.3916 & $0.0294^{*}$ \\
All lakes & 180 & -0.0054 & 0.0150 & 2.7473 & 0.0992 \\
\hline
\end{tabular}

Table 7. Salvelinus fontinalis. Simple regression results of $\delta^{15} \mathrm{~N}$ vs. brook trout length in 8 lakes. ${ }^{* *} \mathrm{p}<0.001,{ }^{*} \mathrm{p}<0.05$

\begin{tabular}{|lcccrc|}
\hline Lake & $\mathrm{n}$ & Slope & $\mathrm{r}^{2}$ & $F$ & $\mathrm{p}$ \\
\hline 1 & 25 & 0.0117 & 0.3302 & 11.3376 & $0.0027^{* *}$ \\
2 & 24 & 0.0045 & 0.5807 & 30.4728 & $<0.0001^{* *}$ \\
3 & 25 & 0.0095 & 0.2344 & 7.0408 & $0.0142^{*}$ \\
4 & 8 & 0.0086 & 0.3880 & 3.8047 & 0.0990 \\
5 & 25 & 0.0152 & 0.7891 & 86.0649 & $<0.0001^{* *}$ \\
6 & 24 & 0.0054 & 0.3904 & 14.0915 & $0.0011^{*}$ \\
7 & 25 & 0.0114 & 0.6383 & 40.5921 & $<0.0001^{* *}$ \\
8 & 24 & 0.0075 & 30.2704 & 8.1535 & $0.0092^{*}$ \\
All lakes & 180 & 0.0064 & 0.2490 & 59.3456 & $<0.0001^{* *}$ \\
\hline
\end{tabular}

very consistent with traditional food-chain models, which attribute trophic positions of 1,2 and 3 relative to primary consumers, predatory macroinvertebrates and fish (Vander Zanden \& Rasmussen 1999). Our results are also consistent with previous isotopic studies in which predatory macroinvertebrates had higher ${ }^{15} \mathrm{~N}$ ratios than primary consumers and fish were enriched in $\delta^{15} \mathrm{~N}$ relative to invertebrates (Vander Zanden \& Rasmussen 1999, Herwig et al. 2004, Anderson \& Cabana 2007). Brook trout exhibited slightly higher $\delta^{15} \mathrm{~N}$ enrichment $(3.77 \%$ ) than the typical assumed shift of 3.4\% per trophic level (DeNiro \& Epstein 1978, Minagawa \& Wada 1984). However, Post (2002) calculated a standard deviation associated with this typical value of $\pm 1 \%$. For predatory macroinvertebrates, the $\delta^{15} \mathrm{~N}$ fractionation value was lower than expected $(2.60 \%$ ). Minagawa \& Wada (1984) reported a wide range in $\delta^{15} \mathrm{~N}$ trophic enrichment values across taxa (0 to $9 \%$ ). Moreover, $\delta^{15} \mathrm{~N}$ trophic enrichment was shown to differ between herbivores $($ mean $=2.5 \%$ o) and carnivores (mean $=3.4 \%$ ) (Vander Zanden \& Rasmussen 2001), suggesting that in our study omnivory (feeding at more than one trophic level) may be important for predatory macroinvertebrates as well. Brook trout, however, is corroborated as carnivorous.

\section{Brook trout diet breadth}

Stable isotopes analyses and mixing models showed that brook trout fed primarily on benthic predatory macroinvertebrates in the 8 Canadian Boral Shield lakes, with a contribution ranging from 60 to $90 \%$ of fish diet. While zooplankton contributed 28 to $37 \%$ in 3 of 8 lakes, it does not appear to be a main source of energy for fish in our lakes. Brook trout, as with other salmonids, are visual predators and are known to feed on the most abundant and visible food, selecting the largest prey items (Allan 
1978). The larger body size of benthic invertebrates relative to pelagic prey makes feeding on benthos more energetically attractive to fish, increasing the efficiency of this trophic link (Vander Zanden et al. 2006). This may explain the greater proportion of benthic macroinvertebrates in fish diet compared to zooplankton in our study, as also shown by other studies (Lacasse \& Magnan 1992, Power et al. 2002, Herwig et al. 2004). Brook trout are known to coexist in many lakes with other species, especially the white sucker Catostomus commersonii, a specialist benthivore (Scott \& Crossman 1973). When living in sympatry with white sucker, brook trout shift their feeding niche from benthic macroinvertebrates to zooplankton in response to interspecific competition for resources (Magnan 1988, Lacasse \& Magnan 1992). In this study, only Lake 8 contained both brook trout and white sucker. In this lake, zooplankton represents $32 \%$ of the diet of brook trout according to mixing models. This is consistent to a certain extent with the brook trout niche shift when living in sympatry with white sucker. However, this may not be the only explanation, as in Lakes 1 and 2 zooplankton also contributed to brook trout diet (28 and 37\% respectively), but in these 2 lakes there was no presence of white sucker. Other lake characteristics may influence brook trout planktonic feeding behavior.

In addition, other studies on brook trout have estimated that they consume between 10 (TremblayRivard 2007) and up to $30 \%$ (Vander Zanden et al. 2006) of terrestrial prey. We have not taken this food source into account and as a result may have underestimated the allochthonous matter source contribution to brook trout diet coming in the form of terrestrial insects. Future studies on brook trout feeding should consider sampling terrestrial prey as a potential food source. Invertebrate isotopic signatures vary in the short term, possibly confounding diet comparisons with fish that have much slower tissue turnover rates. As our sampling was conducted in July, stable isotope results would be limited to the understanding of the feeding behavior of brook trout during spring or early summer.

\section{Brook trout size-related diet shifts}

Ontogenetic diet shifts and size-selective predation are common among fish (Werner \& Gilliam 1984). In our study, $\delta^{13} \mathrm{C}$ signatures exhibited a complex pattern. $\delta^{13} \mathrm{C}$ values became significantly more depleted with increasing fish length in 3 lakes, likely indicating a diet shift related to size. Other studies have shown a significant ${ }^{13} \mathrm{C}$-enrichment with increasing fish length (Grey 2001, Xu et al. 2007), but they considered both alevin and juvenile stages, which was not the case in our study. When all trout stages were considered, Grey (2001) did not find a particular pattern of ${ }^{13} \mathrm{C}$ values in relation to increasing fish length. Furthermore, a change in $\delta^{13} \mathrm{C}$ values is indicative of a shift in benthic or pelagic feeding (Vander Zanden et al. 1998) and expecting that a change in diet (to a different trophic level) can occur without a significant change in $\delta^{13} \mathrm{C}$ may be reasonable. In contrast, in our study, $\delta^{15} \mathrm{~N}$ ratios of brook trout became more positive with increasing fish length in 7 out of 8 lakes. This was also shown in other studies on brook trout (Power et al. 2002, Tremblay-Rivard 2007) and other fish species (Grey 2001, Xu et al. 2007) and is typical of an ontogenetic dietary shift (Power et al. 2002). As a fish increases in length and age, it is capable of handling larger prey items and ingesting later instars of macroinvertebrates and terrestrial insects that fall into the lake (Power et al. 2002).

In conclusion, our study suggests than carbon originating from terrestrial habitat, particularly leaf litter, may significantly contribute to the food web in eastern Canadian Boreal Shield lakes. This study also highlights the importance of carbon produced in benthic habitats to support brook trout in small oligotrophic boreal lakes. Our stable isotope study indicates that benthic macroinvertebrates are important contributors to fish diet. It supports a growing body of literature suggesting that benthic rather than pelagic habitats are the primary energy pathway contributing to fish production (Vadeboncoeur et al. 2002, Herwig et al. 2004, Weidel et al. 2008).

Acknowledgements. This is a contribution to the scientific program of the Chaire de recherche sur les espèces aquatiques exploitées. This research project was supported by a grant from the Fonds de la recherche forestière du Saguenay-Lac-Saint-Jean and Fonds Québécois de la Recherche sur la Nature et les Technologies (FQRNT) to C.N. and P.S. P.G. was supported by a PhD fellowship from FQRNT. P. Bérubé from the Ministère des Ressources naturelles et de la Faune du Québec also contributed to this project. We are grateful to people who contributed to the sampling in the field: M. Bergeron, Y. Bhérer, G. Diab and D. Gauthier. We also thank AbitibiBowater Inc. for providing land use information and field facilities. Two anonymous reviewers provided helpful comments on an earlier version of the manuscript.

\section{LITERATURE CITED}

Allan JD (1978) Diet of brook trout (Salvelinus fontinalis Mitchell) and brown trout (Salmo trutta L.) in an alpine stream. Verh Internat Verein Limnol 20:2045-2050 
Anderson C, Cabana G (2007) Estimating the trophic position of aquatic consumers in river food webs using stable nitrogen isotopes. J N Am Benthol Soc 26:273-285

> Ask J, Karlsson J, Persson L, Ask P, Byström P, Jansson M (2009) Terrestrial organic matter and light penetration: effects on bacterial and primary production in lakes. Limnol Oceanogr 54:2034-2040

> Carignan R, D'Arcy P, Lamontagne S (2000) Comparative impacts of fire and forest harvesting on water quality in Boreal Shield lakes. Can J Fish Aquat Sci 57:105-117

> Carpenter SR, Cole JJ, Pace ML, Van de Bogert M and others (2005) Ecosystem subsidies: terrestrial support of aquatic food webs from ${ }^{13} \mathrm{C}$ addition to contrasting lakes. Ecology 86:2737-2750

> Cole JJ, Carpenter SR, Pace ML, Van de Bogert MC, Kitchell JL, Hodgson JR (2006) Differential support of lake food webs by three types of terrestrial organic carbon. Ecol Lett 9:558-568

$>$ DeNiro MJ, Epstein S (1978) Influence of diet on the distribution of carbon isotopes in animals. Geochim Cosmochim Acta 42:495-506

Edmondson WT (1959) Fresh-water biology, 2nd edn. John Wiley \& Sons, New York, NY

France RL (1997) Stable carbon and nitrogen isotopic evidence for ecotonal coupling between boreal forests and fishes. Ecol Freshw Fish 6:78-83

> Grey J (2001) Ontogeny and dietary specialization in brown trout (Salmo trutta L.) from Loch Ness, Scotland, examined using stable isotopes of carbon and nitrogen. Ecol Freshw Fish 10:168-176

Herwig BR, Soluk DA, Dettmers JM, Wahl DH (2004) Trophic structure and energy flow in backwater lakes of two large floodplain rivers assessed using stable isotopes. Can J Fish Aquat Sci 61:12-22

> Jones RI (1992) The influence of humic substances on lacustrine planktonic food chains. Hydrobiologia 229:73-91

> Karlsson J, Byström P, Ask J, Ask P, Persson L, Jansson M (2009) Light limitation of nutrient-poor lake ecosystems. Nature 460:506-509

> Lacasse S, Magnan P (1992) Biotic and abiotic determinants of the diet of brook trout Salvelinus fontinalis in lakes of the Laurentian shield. Can J Fish Aquat Sci 49: 1001-1009

> Magnan P (1988) Interactions between brook charr, Salvelinus fontinalis and nonsalmonid species: ecological shift, morphological shift and their impact on zooplankton communities. Can J Fish Aquat Sci 45:999-1009

McCutchan JH, Lewis WM, Kendall C, McGrath CC (2003) Variation in trophic shift for stable isotope ratios of carbon, nitrogen and sulfur. Oikos 102:378-390

Merritt RW, Cummins KW (1996) An introduction to the aquatic insects of North America, 3rd edn. Kendall/Hunt Publishing, Dubuque, IA

> Minagawa M, Wada E (1984) Stepwise enrichment of ${ }^{15} \mathrm{~N}$ along food chains: further evidence and the relation between $\delta^{15} \mathrm{~N}$ and animal age. Geochim Cosmochim Acta 48:1135-1140

Pace ML, Cole JJ, Carpenter SR, Kitchell JF and others (2004) Whole-lake carbon-13 additions reveal terrestrial support of aquatic food webs. Nature 427:240-243

Parnell AC, Inger R, Bearhop S, Jackson AL (2010) Source partitioning using stable isotopes: coping with too much variation. PLoS ONE 5:e9672

> Post DM (2002) Using stable isotopes to estimate trophic position: models, methods, and assumptions. Ecology 83: 703-718

Power G (1980) The brook char, Salvelinus fontinalis. In: Balon EK (ed) Charrs, salmonid fishes of the genus Salvelinus. Dr W Junk, The Hague, p 141-203

Power M, Power G, Caron F, Doucett RR, Guiguer KRA (2002) Growth and dietary niche in Salvelinus alpinus and Salvelinus fontinalis as revealed by stable isotope analysis. Environ Biol Fishes 64:75-85

> Premke K, Karlsson J, Steger K, Gudasz C, von Wachenfeldt E, Tranvik LJ (2010) Stable isotope analysis of benthic fauna and their food sources in boreal lakes. J N Am Benthol Soc 29:1339-1348

> Schindler DE, Scheuerell MD (2002) Habitat coupling in lake ecosystems. Oikos 98:177-189

Scott WB, Crossman EJ (1973) Freshwater fishes of Canada. Bull Fish Res Board Can No. 184

Solomon CT, Carpenter SR, Cole JJ, Pace ML (2008) Support of benthic invertebrates by detrital resources and current autochthonous primary production: results from a wholelake ${ }^{13} \mathrm{C}$ addition. Freshw Biol 53:42-54

Solomon CT, Carpenter SR, Clayton MK, Cole JJ, Coloso JJ, Pace ML, Vander Zanden MJ, Weidel BC (2011) Terrestrial, benthic, and pelagic resource use in lakes: results from a three-isotope Bayesian mixing model. Ecology 92: 1115-1125

Stainton MP, Capel MJ, Armstrong FAJ (1977) The chemical analysis of fresh water. Can Fish Mar Serv Misc Spec Publ No. 25

> Tremblay S, Magnan P (1991) Interactions between two distantly related species, brook trout (Salvelinus fontinalis) and white sucker (Catostomus commersom). Can J Fish Aquat Sci 48:857-867

Tremblay-Rivard I (2007) Impacts des coupes forestières sur l'alimentation de l'omble de fontaine (Salvelinus fontinalis) et la structure trophique de lacs en forêt boréale. MS dissertation, Université du Québec à Chicoutimi

> Vadeboncoeur Y, Vander Zanden MJ, Lodge DM (2002) Putting the lake back together: reintegrating benthic pathways into lake food web models. Bioscience 52:44-54

Vander Zanden MJ, Rasmussen JB (1999) Primary consumer $\delta^{13} \mathrm{C}$ and $\delta^{15} \mathrm{~N}$ and the trophic position of aquatic consumers. Ecology 80:1395-1404

Vander Zanden MJ, Rasmussen JB (2001) Variation in $\delta^{15} \mathrm{~N}$ and $\delta^{13} \mathrm{C}$ trophic fractionation: implications for aquatic food web studies. Limnol Oceanogr 46:2061-2066

Vander Zanden MJ, Vadeboncoeur Y (2002) Fishes as integrators of benthic and pelagic food webs in lakes. Ecology 83:2152-2161

Vander Zanden MJ, Cabana G, Rasmussen JB (1997) Comparing the trophic position of freshwater fish calculated using stable nitrogen isotope ratios $\left(\delta^{15} \mathrm{~N}\right)$ and literature dietary data. Can J Fish Aquat Sci 54:1142-1158

> Vander Zanden MJ, Hulshof M, Ridgway MS, Rasmussen JB (1998) Application of stable isotope techniques to trophic studies of age-0 smallmouth bass. Trans Am Fish Soc 127:729-739

Vander Zanden MJ, Chandra S, Park SK, Vadeboncoeur Y, Goldman CR (2006) Efficiencies of benthic and pelagic trophic pathways in a subalpine lake. Can J Fish Aquat Sci 63:2608-2620

Weidel BC, Carpenter SR, Cole JJ, Hodgson J, Kitchell J, Pace ML, Solomon CT (2008) Carbon sources supporting fish growth in a north temperate lake. Aquat Sci 70:446-458 
Welschmeyer NA, Strom S, Goericke R, DiTullio G, Belvin M, Petersen W (1993) Primary production in the subarctic Pacific Ocean: Project SUPER. Prog Oceanogr 32:101-135 Werner EE, Gilliam JF (1984) The ontogenetic niche and species interactions in size-structured populations. Annu Rev Ecol Syst 15:393-425

Whitehead RF, de Mora S, Demers S, Gosselin M, Monfort P,

Editorial responsibility: Asbjørn Vøllestad,

Oslo, Norway
Mostajir B (2000) Interactions of ultraviolet-B radiation, mixing, and biological activity on photobleaching of natural chromophoric dissolved organic matter: a mesocosm study. Limnol Oceanogr 45:278-291

Xu J, Zhang M, Xie P (2007) Size-related shifts in reliance on benthic and pelagic food webs by lake anchovy. Ecoscience 14:170-177

Submitted: March 9, 2011; Accepted: July 30, 2012

Proofs received from author(s): October 16, 2012 